\section{貫彻“厚今薄古”的方針是 世界观的改造問題}

\section{中国科学院哲学研究所 賀 麟}

党中央提出“厚今薄古”方針，对我是一种新的启 示, 我是哀心拥护的。但是，我原先对这个方針的理 解是很表面的，很一般性的。我欢迎这个方針对学术 研究指出了一个新的方向, 但对这个新方向的具体內 容和克服“厚古薄今”的习慣势力的艰巨性缺无䚿識。

知如就西方哲学史来說，最初我总以为在材料 分配上只要減少古希䐳和中世紀哲学的篇幅，垛多近 代和現代哲学，特別是馬克思主义哲学的篇幅就算是 “厚今薄古”了，其次我也只能提出一般地、抽象地貫 彻“厚今薄古”的方針于哲学史研究的三个原則: 第一一, 用发展覌点来研究哲学史，承䚿哲学史是唯物主义对 唯心主义斗爭而讋証发展的历史; 第二, “厚今薄古” 方針要求在哲学史研究中反映时代精触、时代需要; 第三，“厚今薄古”方針要求与当前思想战綫上的斗爭 相結合、相配合。然而我的这种只是一般的、抽象的 理解, 經不任在实际工作斗爭中的考驗。換句話說, 我 搞哲学史是多年来在“厚古薄今”的覌点支配下陶冶出 来的，我过去純粹是走“厚古薄今”的道路，訩为古典 哲学(实际是古典唯心主义哲学)有不少普遍永恆的真 理,我用它的标准来評論当今的哲学,用它的覌点来解 释世界、指导生活。現在如果不用很大力气，連根拔掉 这种代表资产阶級唯心主义世界覌对于旧哲学与新哲 学的关采的錯誤看法，又怎样可能在哲学史的研究中 其彻“厚今薄古”的伟大方針呢?因此我体会到, 要䚿, 真 “貪彻“厚今薄古”的方針, 必須訶㣀进行思想改造, 从根 本上改变自己旧的資产阶級唯心主义世界覌，在学术 思想上进行一个自我革命。不然，我对“厚今薄古”的 方針就会降于抽像贊成，具体反对; 一般贊成，个别反 对; 表面贊成,实质反对的严重錯言吴和危险的泥坑里。

当然，世界覌的改变, 不能只是一般地抽缘地来 談的，而是要經过反复的斗学才能实現的。例如，我 过去用“厚古薄今”的餈产阶級世界覌夫看苏格拉底， 所以多年来对馬克思主义哲学关于苏格拉底的評价有 坻触，我总䚯为苏格拉底是个应該肯定的人物，是“为 黄理而死”的圣人、英雄，一直等到得到“厚今薄古”这 一新方釬的启示，把具体貫彻“厚今薄古”的方針与自 已的思想改造和世界观的改造联系起来，抹以感动慗 敬的心情䚿識到許多无产阶級的革命导师、先烈的伟
大形象以后，才使我逐漸䚯識苏格拉奃是一个为珼族

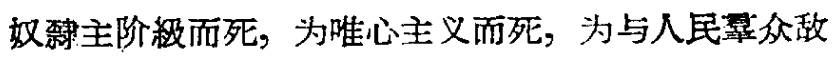
对而死的反动哲学家，才使我逐漸从唯心主义的历央 覌和世界覌中解放出来。

所以“厚今薄古”方針是与世界覌的改 变相 結 合 的。这方針的䚿真貨彻，可以使我們在学术思想上 从旧的資产阶級世界覌中解放出来，使我們䚿識到通 今寸能鉴古，古、古人、古代文化經过新观点批判研 究后是拿来为社会主义建設服务的，不是拿来盲目崇 拜的。我們要厚馬克思列宁主义之今，要厚毛择东时 代之今，要厚社会主义建設、总路綫之今。

\section{我的竐 划}

中国科学院哲学研究所 北京大学 馮 友 兰

解放后，同志們經常問我打算怎样修改我过去所 作的中国哲学史。应該修改的地方实在是太多了，可 是, 那部书的主要問題还不在于有很多枝枝节节的錯 誤，而是在于它是从资产阶級立場，有些部分甚至于从 封建地主的立場, 用資产阶級可史学的覌点和方法写 出来的。它的整个体系是一个資产阶級历史学体系。 要对它作彻底的修改，那就等于重新再写一部。同时 我也覚得只有重写一部中国学史，才能对于我过去 的中国暂学史工作，作一个总的清算。

北京大学哲学系所开的中国哲学史这門功課現在

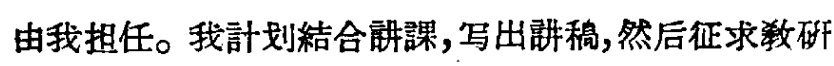
室的同志們和同学們的意見,进行修欧。爭取在这門功 課謰完以后，就写出一部从先秦到五四运动的研稿。 現在已将写完先泰部分。这門坵課两年䛍完, 我計划 于 1960 年完成初稿, 1961 年修改, 1962 年拿出来,作 为第二个五年計划期間我对于社会主义建設的貢献。

这样的工作，要想做好，必須改变我过去的資产 阶称立場和资产阶极历史学的覌点和方法，从无广阶 級的立場, 用馬克思主义的覌点和方法,彻底改写。这 凘不是一件容易的事。方法扭不是中立性的,任何人可 以随便拿来使用。覌点也不是象照相机对光那样，只

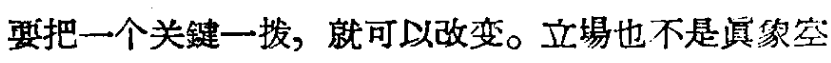
間中的一个地点，人可以随便从一个跳到另一个。立 場覌点和方法，总起来，就是一个人的世界观，就是 他的整个精神面貌。要想改变它，真要象平常所弪的 “脫胎換骨”。我所計划中的䛍稿的水平，是和我的思 想改造分不开的。我孚取在这部貄穆完成的时候，在 紅和专的方面，都有丰收。 